Journal of Social Sciences 6 (1): 41-46, 2010

ISSN 1549-3652

(C) 2010 Science Publications

\title{
Food Security among Households: Evidence from Rice Consumers in Igbemo Region
}

\author{
J.O. Basorun \\ Department of Urban and Regional Planning, Federal University of Technology, \\ Akure Ondo State, Nigeria
}

\begin{abstract}
Problem statement: Less than half the rice consumed in Nigeria was produced locally. Following the sudden rise in the price of imported rice since 2007, Nigerians, no doubt, have faced great risk of increase in the number of hungry by many millions of people. This study unveiled the challenges faced by rice consumers in a rice producing region in Ekiti State, Nigeria. Approach: Five hundred respondents were randomly selected and examined in 16 of the 69 residential quarters which constituted the 6 Local Government Areas (LGAs) in the study region. Data analysis was carried out using simple descriptive statistics such as frequency counts and percentages. Results: Research findings revealed that: (i) the level of consumption of Igbemo rice was high (ii) the product was characterized by contamination (iii) quantity made available in the markets has reduced largely as (iv) production was predominantly seasonal. Conclusion: Policy interventions were advocated based on research findings for improved food security in the region.
\end{abstract}

Key words: Rice, rice consumers, Igbemo region, Ekiti state, Nigeria

\section{INTRODUCTION}

The right to food is a universal one-a right that more than 854 million people worldwide are actually deprived of (Grassmann and Manniged, 2008). Highlighting the views of UN's Food and Agriculture, Fleshman (2008) opines that increased consumption, climate change and growing use of agricultural produce for fuel may mean that the era of cheap global grain supplies is over for good. At present, consumers in many parts of Africa have started turning to locally grown foods as import prices rise (Fleshman, 2008). This is, however, a new challenge that can influence food security. An alternative source of food will be of tremendous advantage, particularly for the poor and play significant role in times of famine and insecurity or when food supply mechanisms are disrupted and people have limited access to food (Grassmann and Manniged, 2008).

Poor families, very often must spend up to three quarters of their income on food (Jury, 2004). Recently, series of unrest and agitation followed the abrupt spike in food prices from the beginning of 2007 in African countries (Harsch, 2008). These includes: Morocco, Mauritania, Guinea, Mozambique, Burkina Faso and Cameroun. Others are Senegal, Coted'Ivoires, Egypt, Tunisia and Gabon. A consultant in agriculture (Audu Ogbeh) has expressed fears over Nigeria's readiness to face food shortage in this period of food crisis; hence, the country needs to improve her local production to sustain itself (Adepetun and Ugwu, 2008).

Rice is the world's most important food product (Bruntrup, 2006), about three billion people worldwide eat rice everyday (Subair, 2008). The average Nigerian consumes $21 \mathrm{~kg}$ of rice year ${ }^{-1}$ (West African Rice Development Association, 2002). The increasing rate of consumption makes Nigeria import-dependent in rice. It produces 2 million tones and consumes about 5 million tones annually, thereby, spends $\$ 800 \mathrm{~m}$ on importation of the deficit of 3 million tones (Awe, 2006). As disclosed by the Minister of Commerce and Industry (Engr. Charles Ugwu), "the $\$ 10$ billion realized from import levy charged rice importers over the years is now channeled toward improving local rice production-an addition to the $\$ 80$ billion formerly dedicated to the improvement of agricultural sector to meet the current global food shortage and to ensure food security in the country (Orintunsin, 2008)".

Rice is one of the most important arable crops grown in Ekiti (Adeola, 2002), especially in Igbemo. The rising interest in its cultivation is on account of the high demand which is partly the result of increasing population growth, income levels and rapid urbanization and associated changes in family occupational structure (Akanji, 1995). It is obvious that, Nigeria like other under-developed countries is still facing a persistent food shortage problem (Sanusi and Salimonu, 2006). The president of Alliance for Green 
Revolution in Africa (AGRA), at the Tokyo International Conference for African Development (TICAD) in Yokohama maintains that, rice represents Africa's best opportunity for reduction of food imports (Abubakar et al., 2008). In view of the significance of rice among the food crops in Nigeria and government commitment to improve local production as earlier noted, the assessment of rice consumption becomes imperative for policy review. The specific objectives of study are to: (i) identify the socio-economic characteristics of the rice consumers in the area (ii) examine the consumers' views about the production and (iii) investigate the links between the centre of production (Igbemo) and human communities within the region.

Conceptual framework: Reduction in the number of people suffering from hunger to half by 2015 tops the list of the eight UN Millennium Development Goals (MDGs). This vision is impractical in many developing nations where food insecurity is prevalent due to their ever increasing populations. Food insecurity is unstable food production and inaccessibility to vital food resource to meet daily food needs of the population (Ajake, 2003). The United Nations Research Institute for Social Development, therefore, considers food security as sustained and assured access by all social groups and individual to food adequacy in quantity and quality to meet their nutritional needs (Esu, 2000).

In Developing Countries, millions of people suffer from hunger and malnutrition. At least 800 million people do not have access to sufficient food to ensure healthy productive lives, while about 170 million children suffer from malnutrition, serious enough to jeopardize their future physical and mental development (Pinstrup-Andersen, 2001). Nigeria, the most populous country, having over 140 million people constitutes about a quarter of the continent's total population and has agriculture as the largest sector of the economy providing about two-third of the nation's workforce (Nigerian Institute of Social and Economic Research, 2002). Agriculture generates employment (both in the agriculture and off-farm sectors), income and provides food security (Braun, 2004). Regardless of the high level of involvement of Nigerians in agriculture, acute shortage in food as a result of low productivity remains a major problem (Okpiliya, 2003).

Of all the food items, rice is the most widely consumed. Nigeria, Cote'd'Ivoire, Zaire and Madagascar are among the highest producer of all types of rice in Africa (Baksh, 2003). Consumers in these countries require that the domestically produce rice should satisfy minimum level of quality, health and food security standards. Since the mid-1970s, rice consumption in Nigeria has risen tremendously $(10.3 \%$ and above annum ${ }^{-1}$ ) as a result of accelerating growth rate $\left(2.8 \%\right.$ annum $\left.^{-1}\right)$ and increasing per capita consumption $\left(7.3 \%\right.$ annum $\left.^{-1}\right)$ due to changing consumer's preference (Akpokodje et al., 2001). Undoubtedly, rice production has also expanded as a result of vast increase in land area put under cultivation. However, this is still considered insufficient to match the consumption increase (Nigerian Institute of Social and Economic Research, 2002).

Beyond the original framework of economic integration, regional needs, resource distribution, social priorities and taste have become increasingly important in regional community planning. Igbemo region is employed in this research to segregate the study area based on some specific criteria. It is adopted to provide deducible description of the importance of Igbemo in relation to the regional rice need. Using certain socioeconomic parameters, a region is seen in two forms; it can be an area within which homogeneity prevails in terms of one or more categories of phenomena (language, religion, occupation, income, climate and relief) or an environment having functional coherence in terms of several interrelated interacting categories of phenomena (Sule, 2008)". Rice production is dominant in Igbemo with an output flow which influences the performance of many other activities in its vicinity. Massive processing activities in the area promote rice marketing which is a source of support for the distributions through a network of linkages and economic relations within the regional communities. The choice of Igbemo region as the intrinsic case study for this research, therefore, is justified by the strategic position of the town in the regional economy.

In delineating the study region, the Access Opportunity Model (AGM) was employed. Accessibility in this context is estimated using the formula:

$$
\mathrm{A} 0_{\mathrm{i}}=\frac{\mathrm{S}_{\mathrm{j}}}{\mathrm{t}_{\mathrm{ij}}^{\mathrm{b}}}
$$

Where:

$\mathrm{A} 0_{\mathrm{i}}=$ Access opportunity index

$\mathrm{S}=$ Size of item required at centre $(\mathrm{j})$

$\mathrm{t}=$ Time taken to travel from residence ' $\mathrm{i}$ ' to acquire item at centre 'j'

$\mathrm{b}=$ Exponent describing distance-decay effect (Morenikeji, 2006; Smith, 1977)

The 16 LGAs that constitute Ekiti State were involved in the estimate. Undoubtedly, their locations from Igbemo vary with distance which is a determinant of their A0. The higher the A0, the higher the access 
level of a particular LGA. The mean A0 for the entire region, therefore, is obtained by multiplying each LGA's A0 by its population, summing the values and dividing with total population thus:

$\mathrm{A}_{\mathrm{i}}=\frac{\sum \mathrm{A}_{\mathrm{i}} \mathrm{xN}_{\mathrm{ij}}}{\sum \mathrm{N}_{\mathrm{j}}}$

The higher the value of $A j$, the better. The number of LGAs that fall below the mean A0 value, however, represent the sub-regions of the state that are of less interaction in terms of access opportunity to the local rice.

It is possible to determine major areas of influence of the local rice using this model. But the usual constraint is determining the application to spatial dimensions. Whether it is better applied to the city or regional level remains a crucial question. What is important, however, is the clear specification of the variables at any given level that reflects the function of a service centre.

\section{MATERIALS AND METHODS}

Research locale: The study region covers 6 out of the 16 Local Government Areas (LGAs) in Ekiti State. They are: Ado, Irepodun/Ifelodun, Ido/Osi, Gbonyin, Oye and Ikole LGAs which accommodates about $44.2 \%$ of the state population. It locates in the northeasten part of the state where it shares boundaries with Ilejemeje and Moba LGAs as well as Kwara State in the North; Ekiti East LGA, Kogi and Ondo State in the East; Emure, Ise-Orun, Ikere and Ekiti South West in the South and Ekiti-West and Ijero in the West. The region lies in the rain fed upland environment where rice is increasingly cultivated in the South-Western Nigeria.

Sampling design and issues: A structured questionnaire was prepared and administered on 500 households' heads (respondents). The target population of this study is Igbemo rice consumers. A multistage random technique was employed in selecting the sample. The first stage involves a contiguous selection of 6 LGA, in Ekiti state as earlier specified. The LGAs have been identified among others in the state as the major catchments of the local rice. The second stage involves the random selection of 18 residential quarters (wards) which represent $26.0 \%$ of the existing 69 wards in the region. A ward in Ekiti is a clearly demarcated political unit by the Independent National Electoral Commission (INEC). This, in reality, is a neighborhood.
Table 1: Socio-economic characteristics of the rice consumers

\begin{tabular}{|c|c|c|c|c|}
\hline Variable & Measurement scale & Frequency & Percentage & Mean \\
\hline \multirow[t]{5}{*}{ Age (years) } & $18-30$ & 160 & 38.3 & \\
\hline & $31-45$ & 174 & 41.6 & \\
\hline & $45-59$ & 59 & 14.1 & \\
\hline & $>60$ & 16 & 6.0 & \\
\hline & Total & 418 & 100.0 & 1.99 \\
\hline \multirow[t]{3}{*}{ Sex } & Male & 156 & 37.3 & \\
\hline & Female & 262 & 62.7 & \\
\hline & Total & 418 & 100.0 & 1.60 \\
\hline \multirow[t]{5}{*}{ Marital status } & Single & 122 & 29.2 & \\
\hline & Married & 256 & 61.2 & \\
\hline & Divorced & 13 & 3.1 & \\
\hline & Widowed & 27 & 6.5 & \\
\hline & Total & 418 & 100.0 & 2.36 \\
\hline \multirow[t]{5}{*}{ Level of education } & Illiterate & 110 & 26.3 & \\
\hline & Primary & 51 & 12.2 & \\
\hline & Secondary & 212 & 50.7 & \\
\hline & Tertiary & 45 & 10.8 & \\
\hline & Total & 418 & 100.0 & 2.92 \\
\hline \multirow[t]{5}{*}{ Major occupation } & Farming & 322 & 77.0 & \\
\hline & Civil service & 19 & 4.6 & \\
\hline & Trading/business & 52 & 12.4 & \\
\hline & Artisan/professional & 25 & 6.0 & \\
\hline & Total & 418 & 100.0 & 2.15 \\
\hline \multirow[t]{6}{*}{ Annual income ( } & $<50,000$ & 68 & 16.3 & \\
\hline & $50,000-100,000$ & 126 & 30.1 & \\
\hline & $100,001-150,000$ & 35 & 20.3 & \\
\hline & $150,001-200,000$ & 116 & 27.8 & \\
\hline & $>200,000$ & 23 & 5.5 & \\
\hline & Total & 418 & 100.0 & 3.51 \\
\hline
\end{tabular}

The sample (500 respondents) was disaggregated into the 18 wards according to the number of buildings which were used as proxy population for consumers' population in each ward. Thereafter, samples were randomly chosen from the wards which represent welldefined Data Delineated Areas (DDAs). In a targeted house, only one household was interviewed and the respondent was the household head of age 18 and above. About $418(83.6 \%)$ of the 500 respondents in the region consume the local rice. Cross sectional data were collected from the sampled rice consumers with the aid of interview schedule which was considered appropriate since some of the consumers were illiterates. The data generated was subjected to simple descriptive statistics such as frequency counts and percentages.

\section{RESULTS}

Socio-economic characteristics of the rice consumers: Table 1 shows the summary of socioeconomic characteristics of rice consumers in the study area. The result reveals that majority of the consumers fall between 31-45 years age bracket (41.6\%). This attests to the fact that bulk of the people are in the active working age. As expected, food such as rice, which is easy to prepare, is of great importance among household with young children. Table 1 also indicates that two of every three rice consumers $(62.7 \%)$ are 
females, majority (61.2\%) of who are married. Cooking remains the exclusive responsibility of women in this age group. As they enter the work force, the opportunity cost of their time increases (Nigerian Institute of Social and Economic Research, 2002) and the preferred food is rice. This is evident in the regularity of consumption $(71.7 \%$ eating rice at least thrice a week).

Results of the findings also reveal that a significant proportion of the consumers are literates $(73.7 \%)$. The average household in Ekiti State often takes advantage of the Government free-education programmes to secondary level. Given that most of the literates are secondary school leavers $(52.9 \%)$ explains the high engagement of the consumers in farming $(77.0 \%)$. Predominantly, the consumers $(66.7 \%)$ earn below $\$ 150,000$ (\$1250.0) annually. This is symptomic of the high rate of unemployment and poverty particularly in Ekiti state. Indeed, poverty index is higher in Ekiti State than the national average (Nigerian Institute of Social and Economic Research, 2002).

Availability of the rice: Availability of the rice gives insight into level of demand. Field survey reveals that $56.0 \%$ of the consumers consider the rice to be fairly available while $42.4 \%$ claim it is quite readily available in the region. Only $1.6 \%$, who perhaps are not regular consumers, feel it is not available. The level of response varies significantly in Ado (State capital) LGA where greater percentage $(71.9 \%)$ experiences insufficient supply. However, $95.7 \%$ agreed that the price is moderate-an indication that the rice is affordable and may be a cheaper substitute to the imported rice.

Seasonality of production: Igbemo grows typically upland rice. Ekiti state generally, enjoys tropical climate with two distinct seasons-rainy season (AprilOctober) and dry season (November-March). The rice farmers clear the land between December and March and prepare it for seeds' broadcast and harrowing at the onset of the rains in early April. Harvesting begins in July, while sun drying after parboiling commences with the milling operations simultaneously. Traditionally, the rice farmers $(99.1 \%)$ in Igbemo rely on previous self-harvest for the new year planting. In effect, the level of availability of the rice depends largely on the seasonal nature of production in the town.

Quality of the rice: In two-third (66.6\%) of the regional communities, the issue of quality tends not to exert any influence on consumption as 54.3 and $10.1 \%$ of the respondents agreed that the rice is good and very good respectively. Only $33.1 \%$ argued that it was fair, while extremely few $(2.6 \%)$ claimed it was poor. These are elite and urban residents of Ado and Ikole, who consider standard hygiene in rice production and handling important. However, consumers noticed major qualitative deficiencies of the rice to include presence of pebbles (68. 9\%); a problem which $87.5 \%$ associated with processing (parboiling/drying and milling) and presence of chaff $(20.4 \%)$.

Need to strengthen production: Records have shown that rice is a common food and that a large percentage $(82.8 \%)$ of the consumers in the region, source the product from Igbemo. The study area significantly depends on agricultural production, especially rice. But productivity is low because, the production system is characterized by primitive technologies, poor organizations and limited physical and human capital inputs.

\section{DISCUSSION}

In the urban centre, the commodity faces stiff competition with imported rice consumption since the average income of the consumer in this place tends to be relatively higher than any other part of the region. Generally, bulk of the consumers in the region experiences shortage of the commodity. This indicates danger for food security, in terms of "ability to meet target consumption level in the face of fluctuation in production, prices and incomes together with ensuring absolute availability at any time (Sanusi and Salimonu, 2006; World Bank, 1986)".

With the present farming culture in Igbemo, rice consumers in the region face long period (about 7 months) of short supply every year. It has been observed that less than half of rice consumed in subSaharan African is supplied locally (Abubakar et al., 2008). Predominantly, the consumers are poor and live in local environment where quality may not necessarily be a priority. However, in more metropolitan societies, consumption appears to have altered with quality factors rather than just availability which initially has been the basis for choice of rice (Nigerian Institute of Social and Economic Research, 2002).

In Igbemo, rice milling is done in mechanized units with the old conodisc technology, while drying of parboiled rice is done usually on unprotected concrete floors and sometimes by the road side, thus, exposing the product to contamination by insects, dirts and animals excreta. As expected, there is complete absence of destoners and modern technology of drying and milling of local rice in most developing countries (Fellows, 2002). 
It is obvious that significant number of processors and marketers exist in the region to make the rice product available to consumers because of "the vast growing demand for food in Nigeria today (Balarabe et al., 2006)". It is also evident that majority of the farmers in Igbemo engage in rice cultivation as a profitable venture. Given that production has increased slightly in recent times with regular consumption, the efforts to improve efficiency of production and substantially increase average per hectare yield of rice in Igbemo becomes a top-priority development objective.

\section{CONCLUSION}

This study has identified the household requirements in rice consumption in a rice producing region in Nigeria. The study has sourced for data among five hundred consumers in the region using a multistage random technique to select the samples. Important findings from the analysis are that:

- Most of the consumers are of the active working age who source rice frequently from Igbemo

- Majority of them hardly secure the commodity in sufficient quantity due to seasonality of production

- Consumption is higher in the urban than rural areas where quality is a priority

In the region, there is heavy dependence on Igbemo rice which the working age often purchases from the periodic neighborhood market. Periodicity of supply dominates the marketing structure because; the marketers assemble the product in reasonable quantities for the next market after a market operation. To ensure regularity of supply, the Local Government should establish Rice Marketing Centers (RMCs) in their respective headquarters. This will represent a major depot of the wholesalers within a framework of regional communities where consumers can frequently access the product at a minimum cost.

As observed, scarcity of rice accompanies seasonality of production at source. Ekiti State government through the Agricultural Development Project (ADP) should promote mechanization of rice farming in Igbemo under a special agricultural extension programmes. With this policy, rice farmers will be encouraged to hire modern farm equipments at subsidized rate and acquire basic knowledge of irrigation in field operations for regular production.

The issue of security and safety is now a global requirement in the food industry. This involves meeting the nutritional needs of the people in terms of quantity and quality. More people in the urban centers of Ado and Ikole demand the rice with possible improvement in quality than the rural areas. To boost the quality, therefore, the State Government in collaboration with the Department For International Development (DFID) and notable marketing companies should support rice processing in Igbemo with modern milling facilities to destone and polish the rice product for exportation beyond the regional boundaries.

\section{REFERENCES}

Abubakar, M., C. Olayinka and Q. Shady, 2008. NEPAD Japan to Raise Rice Production in Africa? The Guardian, 1.

Adeola, C., 2002. Analysis of Economic Efficiency of Male and Female Rice Farmers in Ekiti State Nigeria. Nigerian Institute of Social and Economic Research, ISBN: 10: 9781813172, pp: 48.

Adepetun, A. and E. Ugwu, 2008. Food Price Crisis: Nigeria Braces up the Guardian. pp: 27-29.

Ajake, A. O., 2003. Population Changes and Food Insecurity in Niger Delta. Glob. J. Soc. Sci., 2: 45-53.

Akanji, B.O., 1995. Hedonic-price analysis of the demand for grain crops in Nigeria: The case of Rice and Cowpea. Ph.D. Thesis, University of Ibadan, Ibadan, Nigeria.

Akpokodje, G., F. Lancon, and O. Erenstein, 2001. Nigeria's Rice Economy: State of the Art. Draft Report, WARDA-NISER, Collaborative study. http://pdf.dec.org/pdf_docs/Pnadb851.pdf

Awe, O., 2006. Ban on Rice Importation Depresses Global Trade, Punch 3.

Balarabe, A.S., B. Ahmend and D.O. Chikwendu, 2006. Analyses of price and income elasticities for cereals food crops in an urban town of Kaduna, Nigeria. Agrosearch, 8: 59-66. http://ajol.info/index.php/agrosh/article/view/39439

Baksh, D., 2003. The right way to process rice. J. Afr. Farm, 26.

Bruntrup, M., 2006. The rice market in Senegal. Agric. Rur. $\quad$ Dev., $13:$ 1-23. http://www.rural21.com/uploads/media/ELR_engl_ 22-25.pdf

Braun, J.V., 2004. Towards a renewed focus on rural development. Agric. Rural Dev., 11: 5.

Esu, I.E., 2000. Food Security and the Sustenance of Democracy. In: Civil Society and the Consolidation of Democracy in Nigeria, Uya, O.E. (Ed.). Cets Publishers, Calabar.

Fellows, P., 2002. The food production-distribution chain. Agric. Rural Dev., 1: 14. 
Fleshman, M., 2008. Africa struggles with soaring food prices. Afr. Renew., 22: 1-12.

Grassmann, R. and E. Manniged, 2008. Management of biological diversity and food security. Int. J. Rural Dev., 42: 20.

Harsch, E., 2008. Price protests expose state faults: Rioting and repression reflect problems of African Governance. Afr. Renew., 22: 1-15. http://www.un.org/ecosocdev/geninfo/afrec/vol22n o2/222-price-protests.html

Jury, A., 2004. Reaching the hungry with food aid. Agric. Rural Dev., 2: 31-33.

Morenikeji, W., 2006. Research and Analytical Methods for Social Scientists, Planners and Environmentalists. Jos University Press Ltd., pp: 106.

Nigerian Institute of Social and Economic Research, (NISER), 2002. Assessment of the economic, social and environmental impacts of rice production in Nigeria within the trade liberalization framework. A Research paper.

Okpiliya, F.I., 2003. Variation of rice yield with temperature and rainfall at Ogoja, Nigeria. J. Agric. Sci., 2: 98-101.

Orintunsin, J., 2008. Food crisis: Federal government earmarks N10b for rice production. Nation, 12.

Pinstrup-Andersen, P., 2001. Emerging Food and Agriculture Concerns in the Developing World Agriculture and Rural Development. 2nd Edn., pp: 20-22.
Sanusi, A.A. and K.K. Salimonu, 2006. Food security among households: Evidence from yam production economics in Oyo state, Nigeria. Agric. J., 1: 235239. http://medwelljournals.com/fulltext/aj/2006/235239.pdf

Smith, D.M., 1977. Human Geography: A Welfare Approach. Hodder and Stoughton Educational, London, ISBN: 10: 0713159251, pp: 416.

Subair, G., 2008. Nigeria spends N100bn yearly to import Rice, Nigerian Tribune, 3. http://www.nigeria70.com/nigerian_news_paper/ni geria_spends_n100bn_yearly_to_import_rice_yar_ rsquo_adua/75201

Sule, R.A.O., 2008. Paradigms of Regional Development Planning in Africa: Theory and Practice, Calabar, Prathel (Nig) Enterprises 19.

West African Rice Development Association, (WARDA), 2002. Nigeria Potential in the Rice Sector, WARDA and the Role of Rice in Nigeria. News Release, 4.

World Bank, 1986. Poverty and hunger: Issues and options for food security in developing countries. World Bank, Washington DC., USA. http://www.popline.org/docs/0917/052764.html 